Acta vet. scand. $1969,10,234-254$.

From The National Veterinary Institute and The Royal Veterinary College, Stockholm, Sweden.

\title{
STUDIES ON ASPERGILLUS FUMIGATUS; PROPERTIES OF INTRACELLULAR PROTEINASE
}

\author{
By \\ Lars Rutquist
}

Mycelial filtrate from Aspergillus fumigatus (AF), following incubation at $37^{\circ} \mathrm{C}$ for 3 days, showed not only haemolytic and toxic but also casein precipitating and proteolytic activity (cf. Rutqvist 1969, with references). The present work has been devoted to an investigation of the latter 2 activities.

\section{MATERIALS AND METHODS}

Strains. In all these experiments, AF strain 6869 from a previously described collection (Rutqvist 1965) was used. In the serological investigations the 13 additional AF strains included in the collection were also utilized.

Media. The strains were cultivated at room temperature on Sabouraud agar slants, with transfers being made once a month. Cultures for producing mycelial filtrate were grown in a liquid medium, comprising proteose-peptone Difco $(1.5 \%)$, yeast extract Difco $(0.5 \%)$, dextrose $(3 \%)$, and $\mathrm{NaCl}(0.5 \%)$ in distilled water $\mathrm{pH} 7.2$.

Buffer solutions. The buffer solutions used in protein hydrolysis were all $0.45 \mathrm{M}$, viz. citrate buffer $(\mathrm{pH} 1.5-4.2)$, acetate buffer ( $\mathrm{pH}$

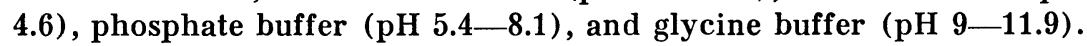
Other buffer solutions that were used will be mentioned in connection with the individual experiments. The $\mathrm{pH}$ values given in the figures are those of the reaction mixtures.

Filtrate preparation. Stock cultures grown for 7 days on Sabouraud agar slants were suspended in $10 \mathrm{ml}$ proteose-peptone broth for each tube, $1 \mathrm{ml}$ of the resultant suspension then being transferred to $300 \mathrm{ml}$ liquid medium in Roux flasks. At the harvest, the mycelial mats present on the surface of the medium after 3 days' incubation at $37^{\circ} \mathrm{C}$ were washed with sterile distilled water, ciried between filter papers, and stored at $-20^{\circ} \mathrm{C}$ during $2-4$ days. 
$100 \mathrm{~g}$ of the frozen mycelial material and $75 \mathrm{ml}$ sterile distilled water were mixed, the mixture then being homogenized in a mixer running at 11,000 r.p.m. The homogenized material was stored for 5 days at $4^{\circ} \mathrm{C}$ and centrifuged at $2,500 \times \mathrm{g}$ for $20 \mathrm{~min}$. The supernatant liquid was subsequently filtered through a Seitz EK filter. The filtrate was stored at $-20^{\circ} \mathrm{C}$.

Antiserum. Immunization of rabbits against mycelial filtrate from AF strain 6869 was initiated by a series of injections of filtrate that was $0.06 \mathrm{M}$ with respect to formaldehyde and had been stored in an incubator at $37^{\circ} \mathrm{C}$ for 5 days (Rutqvist 1968). The formalintreated filtrate was mixed with the same amount of Difco Bacto adjuvant complete. The mixture was injected on 4 occasions in doses of $2,3,4$, and $5 \mathrm{ml}$ intramuscularly at weekly intervals. Two weeks after the last injection in this series another series of $0.5,0.6,0.7,0.8$, and $1 \mathrm{ml}$ formalin-treated filtrate was injected intravenously at 3-4day intervals. The immunization was completed by 4 intravenous injections of $0.01,0.1,0.2$, and $0.5 \mathrm{ml}$, respectively, of untreated filtrate, corresponding to $4-200 \mathrm{MLD}_{50}$ of toxin ${ }^{\star}$ ), which were administered at 3-4-day intervals. Serum was collected 14 days after the last injection. After heating the serum at $56^{\circ} \mathrm{C}$ for $30 \mathrm{~min}$., merthiolate to $0.01 \%(\mathrm{w} / \mathrm{v})$ was added. The serum was then stored at $4^{\circ} \mathrm{C}$.

Normal serum. This was obtained from apparently healthy rabbits and stored at $4{ }^{\circ} \mathrm{C}$, following heating at $56^{\circ} \mathrm{C}$ for $30 \mathrm{~min}$. and addition of $0.01 \%(\mathrm{w} / \mathrm{v})$ merthiolate (final concentration).

Determination of proteolytic activity. Determinations of the proteolytic activity of the mycelial filtrate were carried out using casein and haemoglobin as substrates. The hydrolytic effect of the filtrate on the 2 substrates was denominated "caseinase activity" and "haemoglobinase activity", respectively.

The determinations of caseinase activity were performed by a modification of the Kunitz (1947) method. Four g sodium caseinate (Hammarsten grade, Hopkins \& Williams Ltd., Chadwell Heath, England) were mixed with $4 \mathrm{ml} 1 \mathrm{~N}-\mathrm{NaOH}, 36 \mathrm{~g}$ urea (Wallenfels 1950, Dworschack et al. 1952), $1 \mathrm{ml} 1 \%(\mathrm{w} / \mathrm{v})$ merthiolate, and distilled water to make $100 \mathrm{ml}$. Haemoglobinase activity was determined in accordance with a modification to the original (1938) Anson method. Four $g$ bovine haemoglobin (enzyme substrate powder, Armour Pharmaceutical Company Ltd., Eastbourne, England) were mixed with $8 \mathrm{ml} 1 \mathrm{~N}-\mathrm{NaOH}, 36 \mathrm{~g}$ urea and $1 \mathrm{ml} 1 \%(\mathrm{w} / \mathrm{v})$ merthiolate. Distilled water was added to make $100 \mathrm{ml}$. The substrate mixtures were kept under frequent stirring at room temperature during 4-5 hrs. With all ingredients dissolved $\mathrm{pH}$ was adjusted to 7.5 by means of $2 \mathrm{~N}-\mathrm{HCl}$ and the substrate solutions were then stored at $-20^{\circ} \mathrm{C}$.

*) The filtrate preparation of AF strain 6869 used in these experiments had titres for toxic activity measured as $\mathrm{LD}_{50}$ for mice $\left(\mathrm{MLD}_{50}\right)$ and for haemolytic activity (HU) of $10^{-2.6} \mathrm{ml}$ and $2^{-10} \mathrm{ml}$, respectively. Determinations of $\mathrm{MLD}_{50}$ und $\mathrm{HU}$ were made according to carlier descriptions (Rutquist 1968). 
The determination of protein hydrolyzing activity was performed in a reaction mixture made up of $2 \mathrm{ml} 0.45 \mathrm{M}$ buffer solution, $1 \mathrm{ml}$ $4 \%$ substrate solution and $0.5-1 \mathrm{ml}$ dialyzed filtrate solution. Following incubation (further details are to be found under Figures) the hydrolysis was discontinued by addition of $5 \mathrm{ml} 0.3 \mathrm{M}$ trichloroacetic acid solution (TCA). The mixture was allowed to stand at room temperature for $1 \mathrm{hr}$. after which the precipitate was removed by filtration. The amount of TCA-soluble degradation products was determined by measuring the optical density of the TCA filtrate, using a Beckman, type DK-2 spectrophotometer operating at $280 \mathrm{~m} \mu$. The increase in optical density of the sample as compared to that of a blank for each sample was used as a measure of the enzymatic activity of the filtrate. The blank differed from the sample in that buffer solution mixed with filtrate solution was incubated separately and the substrate solution, which was incubated during the same length of time, was not incorporated until the TCA solution had been added.

Determination of the effect of normal serum and antiserum on the casein hydrolyzing activity of mycelial filtrate

To determine the inhibitory effect of serum on the casein hydrolyzing activity of mycelial filtrate samples of $5 \mathrm{ml}$ dialyzed filtrate were mixed with $2,3,4$, and $5 \mathrm{ml}$, respectively, of normal serum or antiserum, sterile distilled water then being added to make $10 \mathrm{ml}$. Five ml filtrate mixed with sterile distilled water to $10 \mathrm{ml}$ was used as a reference. The filtrate-serum mixtures and the reference sample were incubated for $60 \mathrm{~min}$. at $37^{\circ} \mathrm{C}$ and the caseinase activity of $1 \mathrm{ml}$ filtrate-serum mixture and of the reference sample were then determined at $\mathrm{pH}$ values $2.9,6.2$ and 10. The hydrolysis was carried out at $37^{\circ} \mathrm{C}$ during $90 \mathrm{~min}$.

Determination of the effect of normal serum and antiserum on the casein precipitating activity of mycelial filtrate

The effect of various serum fractions on the casein precipitating activity of mycelial filtrate was investigated in compliance with the method of Sandvik $(1962,1967)$. Following serum electrophoresis the strips of wet paper were applied to the surface of a $2 \mathrm{~mm}$ layer of casein agar in plexiglas dishes measuring $12 \times 22 \times 0.5 \mathrm{~cm}$. After incubation at $37^{\circ} \mathrm{C}$ for $3 \mathrm{hrs}$. the strips were removed and replaced by $0.5 \times 18 \mathrm{~cm}$ strips of filter paper that were moistened with mycelial filtrate solution. Following incubation at $37^{\circ} \mathrm{C}$ during $4-12 \mathrm{hrs}$. these paper strips were also removed and the precipitation was determined.

The casein agar was prepared according to a method previously described by Rutqvist (1969), involving dissolution of $4 \mathrm{~g}$ sodium caseinate (Hammarsten grade) in $100 \mathrm{ml}$ distilled water while adjusting $\mathrm{pH}$ to 7.5. The definite composition of the casein agar was as follows: $0.25 \%$ casein, $1.5 \%$ Bacto-Agar Difco, $0.004 \mathrm{M}-\mathrm{MgCl}_{2}$, added as an $8 \%(\mathrm{w} / \mathrm{v})$ solution, and $0.01 \%(\mathrm{w} / \mathrm{v})$ merthiolate; $\mathrm{pH} 6.2$. 
Paper electrophoresis of serum. A number of paper strips (Schleicher \& Schüll No. 2043 B) $4 \mathrm{~cm}$ wide were wetted with $10 \mu \mathrm{l}$ serum each along a $3 \mathrm{~cm}$ line perpendicular to the length of the strip and then fractionated electrophoretically in an electrophoresis apparatus (DeLuxe Electrophoresis Chamber, Gelman Instrument Company, Ann Arbor, Mich., USA), using an 0.05 M phosphate buffer of pH 6.4. Electrophoresis was continued for $17 \mathrm{hrs}$. at a current of $0.25 \mathrm{mamp} . / \mathrm{cm}$ and a potential gradient of $5 \mathrm{v} / \mathrm{cm}$. Each serum fractionation was duplicated, 1 paper strip being transferred to casein agar and the other being dried at $100^{\circ} \mathrm{C}$ for $30 \mathrm{~min}$. and stained. The staining solution was prepared by dissolving $7 \mathrm{~g}$ Amidoschwarz $10 \mathrm{~B}$ (Merck) in $1 \mathrm{l}$ af a mixture of $45 \%$ distilled water, $45 \%$ methanol and $10 \%$ acetic acid. The staining time was $10 \mathrm{~min}$. Decolorization was then effected in a series of 4 baths containing the watermethanol-acetic-acid mixture. The entire decolorization procedure was completed in $2 \mathrm{hrs}$.

The relative amounts of the various serum fractions were determined photometrically by a scanner (Evans Electroselenium Ltd., Harlow, Essex, England) after rendering the paper strips transparent by means of liquid paraffin. The absolute amount of $\gamma$-globulin in normal serum and antiserum was calculated from the relative amount and the protein content of each individual serum.

Dialysis. The mycelial filtrate was dialyzed against ordinary running tap water for $17 \mathrm{hrs}$. and subsequently against sterile distilled water for $2 \mathrm{hrs}$. The dialyzed filtrate was mixed with $1 \%$ butanol ( $\mathrm{v} / \mathrm{v}$, final concentration).

pH determination. All $\mathrm{pH}$ determinations were performed by means of a glass electrode, using a $\mathrm{pH}$ meter of the type 28 made by Radiometer, Copenhagen, Denmark.

Nitrogen determination. Determinations of the nitrogen content in filtrates and sera were carried out according to the micro-Kjeldahl technique. The factor, 6.25 was used in converting nitrogen content into protein content.

\section{EXPERIMENTS AND RESULTS}

Absorption spectrum. Fig. 1 shows the u.v. absorption spectrum of dialyzed filtrate that had been diluted with $0.15 \mathrm{M}$ phosphate buffer ( $\mathrm{pH} 6$ ) to a final nitrogen concentration of $0.004 \%$. Maximum absorption occurred at $275 \mathrm{~m} \mu$.

Effect of $\mathrm{pH}$ on proteinase activity. Dialyzed filtrate when acting upon casein that had been buffered at various $\mathrm{pH}$ values resulted in 3 clearly different activity optima at $\mathrm{pH} 2.9,6.2$ and 10 , with maximum activity at $\mathrm{pH} 6.2$. With haemoglobin as substrate, maximum activity was recorded at $\mathrm{pH}$ 4.6. Moderate activity optima were recorded at $\mathrm{pH} 3.6$ and 10. The activity curves are reproduced in Fig. 2. 


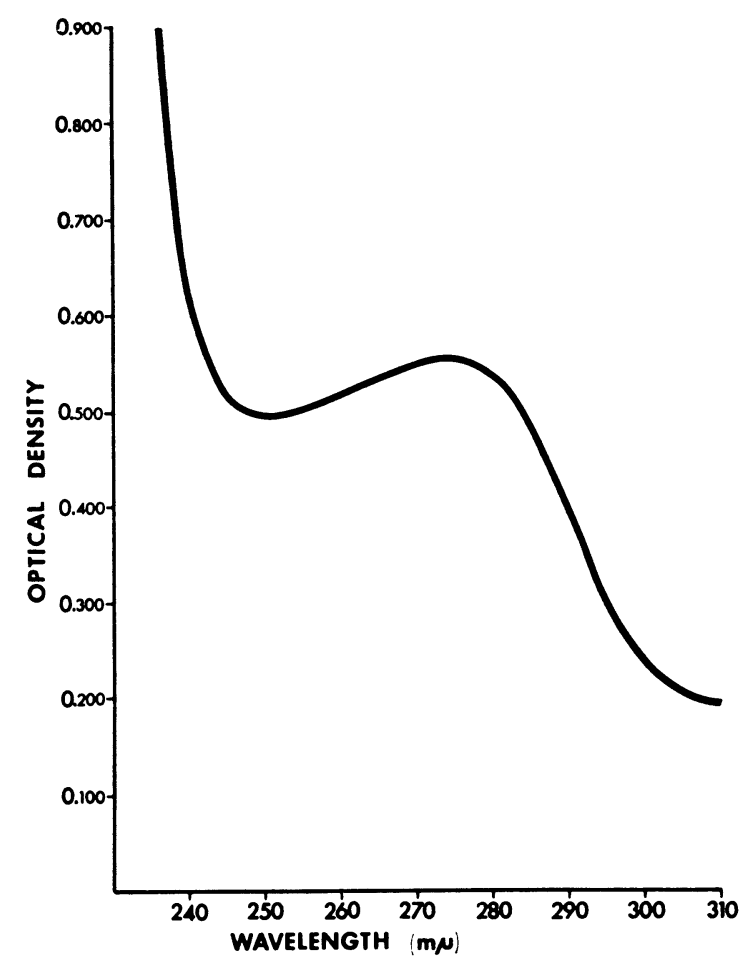

Fig u r e 1. Ultraviolet absorption spectrum of dialyzed mycelial filtrate diluted with $0.15 \mathrm{M}$ phosphate buffer, $\mathrm{pH} 6$, to a nitrogen content of $0.004 \%$. Aspergillus fumigatus strain 6869 .

Effect of $p H$ on the inactivation of proteinase activity. As can be seen from Fig. 3, maximum caseinase activity at $\mathrm{pH} \mathbf{2 . 9}$, following storage at $4^{\circ} \mathrm{C}$, was found in filtrates stored at $\mathrm{pH}$ $6-7$, whereas at $\mathrm{pH} 6.2$ and $\mathrm{pH} 10$ maximum activity was recorded in filtrates that had been stored at $\mathrm{pH} 4$. In the latter case the activity at $\mathrm{pH} 2.9$ and 6.2 , proved to possess great stability against i.e. close to the original $\mathrm{pH}$ value (7.3) of the dialyzed filtrate. The caseinase activity at $\mathrm{pH} 10$, in contrast to the corresponding activity at $\mathrm{pH} 2.9$ and 6.2 , proved to possess great stability against high $\mathrm{pH}$ values. There was no noticeable decrease in caseinase activity at $\mathrm{pH} 10$ in filtrates that had been stored at $\mathrm{pH} 5-11$. The activity at $\mathrm{pH} 2.9$ and $\mathrm{pH} 6.2$ dropped in filtrates stored at $\mathrm{pH}>7.5$. The caseinase activity at $\mathrm{pH} 2.9$ and $\mathrm{pH} 6.2$ showed a greater stability against low $\mathrm{pH}$ values than the corresponding activity at $\mathrm{pH} 10$. 


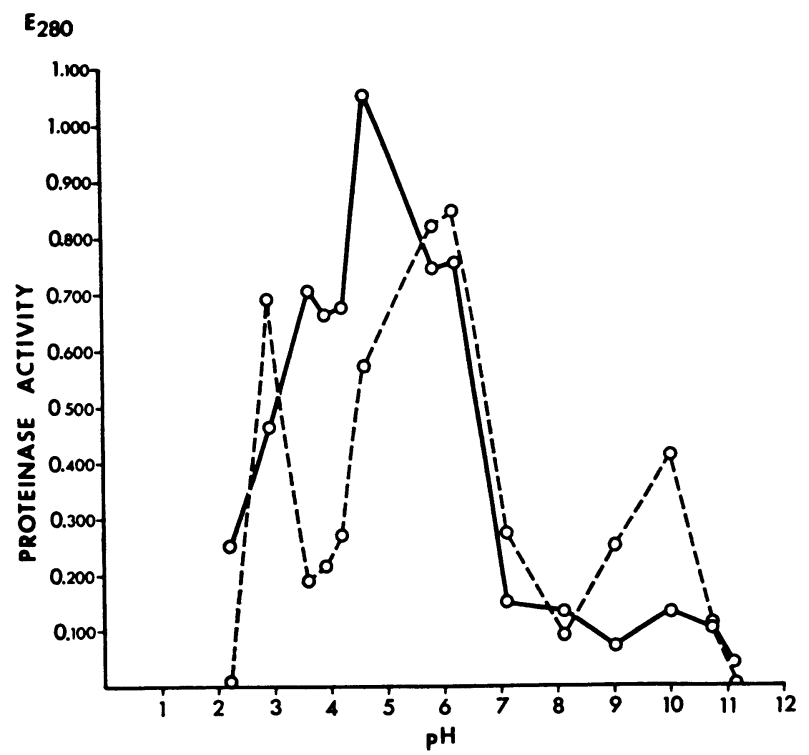

Fig u r e 2. Effect of $\mathrm{pH}$ on the proteinase activity of mycelial filtrate from Aspergillus fumigatus strain 6869. Basic procedure of protein hydrolysis: a reaction mixture of $0.5 \mathrm{ml}$ of filtrate, $1 \mathrm{ml}$ of $4 \%$ substrate solution and $2 \mathrm{ml}$ of buffer was incubated at $37^{\circ} \mathrm{C}$ for $90 \mathrm{~min}$.

o-o haemoglobinase activity.

o-- - - o caseinase activity.

Effect of incubation temperature on proteinase activity. The hydrolysis of casein at $\mathrm{pH} 2.9$ showed a maximum after incubation at $40^{\circ} \mathrm{C}$ (Fig. $4 \mathrm{~A}$ ), at $\mathrm{pH} 6.2$ after incubation at $45^{\circ} \mathrm{C}$ (Fig. 4B) and at $\mathrm{pH} 10$ after incubation at $35^{\circ} \mathrm{C}$; in the latter case, however, maximum hydrolysis after $30 \mathrm{~min}$. incubation occurred after incubation at $40^{\circ} \mathrm{C}$ (Fig. 4C). Casein hydrolysis at $\mathrm{pH} 2.9$ and $\mathrm{pH} 10$ was low in both cases at incubation temperatures above $40^{\circ} \mathrm{C}$, and no definite caseinase activity was recorded at $50^{\circ} \mathrm{C}$. As can be seen in Fig. $4 \mathrm{~B}$ caseinase activity at $\mathrm{pH} 6.2$ occurred over a broad temperature range and could be recorded even after incubation at $65-70^{\circ} \mathrm{C}$.

Caseinase and haemoglobinase activity in relation to nitrogen content. When dialyzed mycelial filtrates containing $50-250 \mu \mathrm{g}$ $\mathrm{N} / \mathrm{ml}$ were allowed to act upon casein that was buffered at $\mathrm{pH}$ 6.2 or on haemoglobin buffered at $\mathrm{pH} 4.6$ there was an increase 


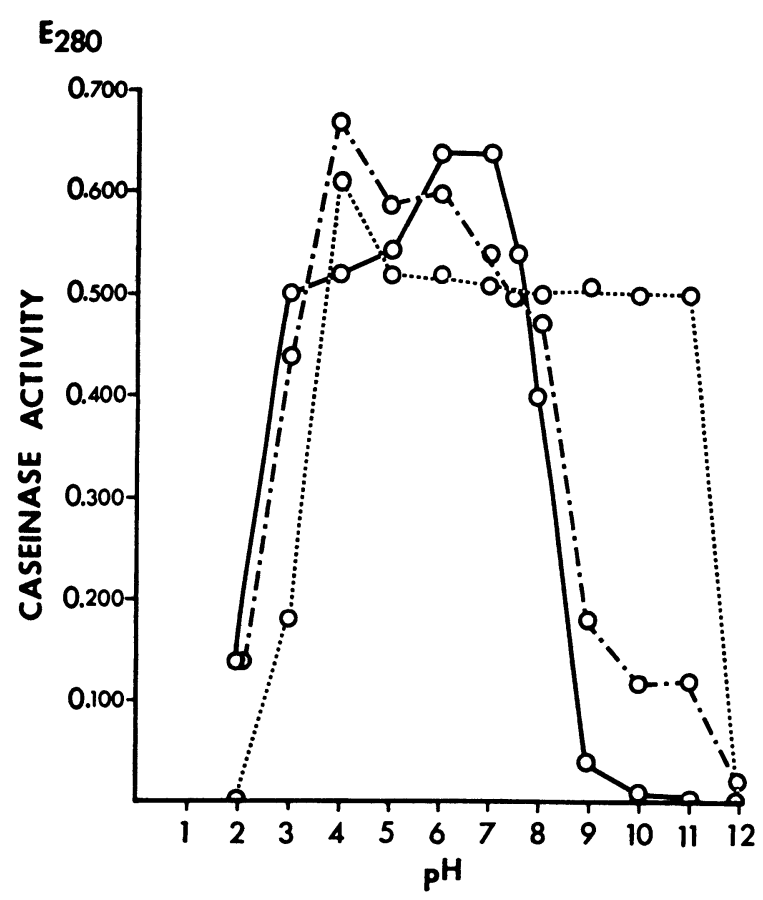

F i g u r e 3. pH stability of the caseinase activity of mycelial filtrate from Aspergillus fumigatus strain 6869 .

Dialyzed filtrate in volumes of $4 \mathrm{ml}$ was adjusted to different $\mathrm{pH}$ values with $0.1 \mathrm{~N}-1 \mathrm{~N}-\mathrm{HCl}$ and $0.1 \mathrm{~N}-1 \mathrm{~N}-\mathrm{NaOH}$, respectively. After being kept at $4^{\circ} \mathrm{C}$ for $90 \mathrm{~min}$. the filtrate was neutralized. The volumes were corrected with distilled water and the caseinase activity at $\mathrm{pH}$ 2.9 , $\mathrm{pH} 6.2$ and $\mathrm{pH} 10$, respectively, was determined. Basic procedure of casein hydrolysis: a reaction mixture of $0.5 \mathrm{ml}$ of filtrate, $1 \mathrm{ml}$ of $4 \%$ casein solution and $2 \mathrm{ml}$ of buffer was incubated at $37^{\circ} \mathrm{C}$ for $90 \mathrm{~min}$.

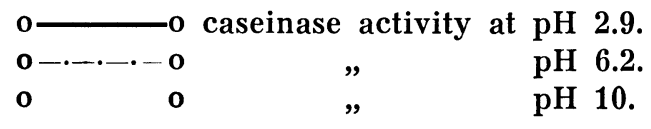

in caseinase and haemoglobinase activity, respectively, at increasing nitrogen content, as can be seen from Fig. 5. Under the prevailing experimental conditions the graph representing the correlation between caseinase activity and nitrogen content of the filtrate was rectilinear whereas no rectilinear correlation could be found for the haemoglobinase activity of filtrates containing more than $100 \mu \mathrm{g} \mathrm{N} / \mathrm{ml}$. 

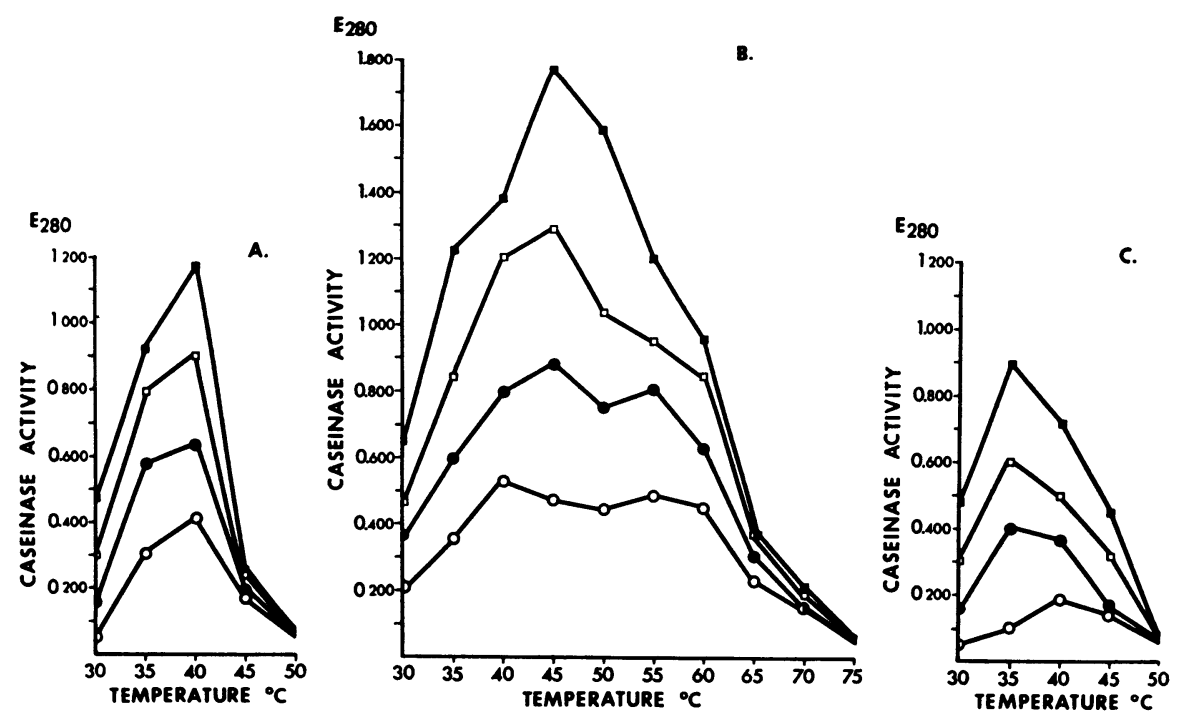

F i g u r e 4. Optimum incubating temperature for casein hydrolysis

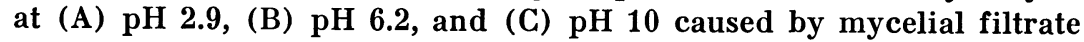
from Aspergillus fumigatus strain 6869. Basic procedure of casein hydrolysis: a reaction mixture of $0.5 \mathrm{ml}$ of filtrate, $1 \mathrm{ml}$ of $4 \%$ casein solution and $2 \mathrm{ml}$ of buffer was incubated in a water bath at different temperatures for $30,60,90$, and $120 \mathrm{~min}$.

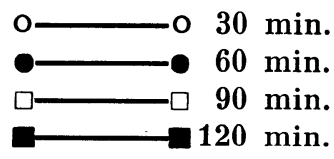

Effect of heat in relation to $\mathrm{pH}$ on proteinase activity. Filtrates of $\mathrm{pH} \mathrm{7.3,} \mathrm{when} \mathrm{heat} \mathrm{treated} \mathrm{for} 2 \mathrm{hrs}$. at temperatures in the $40-70^{\circ} \mathrm{C}$ range, showed a caseinase activity at $\mathrm{pH} 10$ that was more heat stable than the caseinase activity at $\mathrm{pH} 2.9$ or pH 6.2 (cf. Fig. 6). So, at $\mathrm{pH}$ values 2.9 and 6.2 , respectively, no caseinase activity could be detected after heat treatment at $55^{\circ} \mathrm{C}$ whereas the filtrate still retained $19 \%$ residual activity at pH 10 following heat treatment at $70^{\circ} \mathrm{C}$.

In filtrates that had been heat treated at $\mathrm{pH} 3, \mathrm{pH} 8$ or $\mathrm{pH} 10$ the caseinase activity determined at $\mathrm{pH} 2.9$ and $\mathrm{pH} 10$ showed clearly divergent inactivation curves (Figs. 7A, C, D). The strongest residual caseinase activity as determined at $\mathrm{pH} 2.9$ occurred in filtrates that had been heat treated at $\mathrm{pH} 3(83 \%$ 


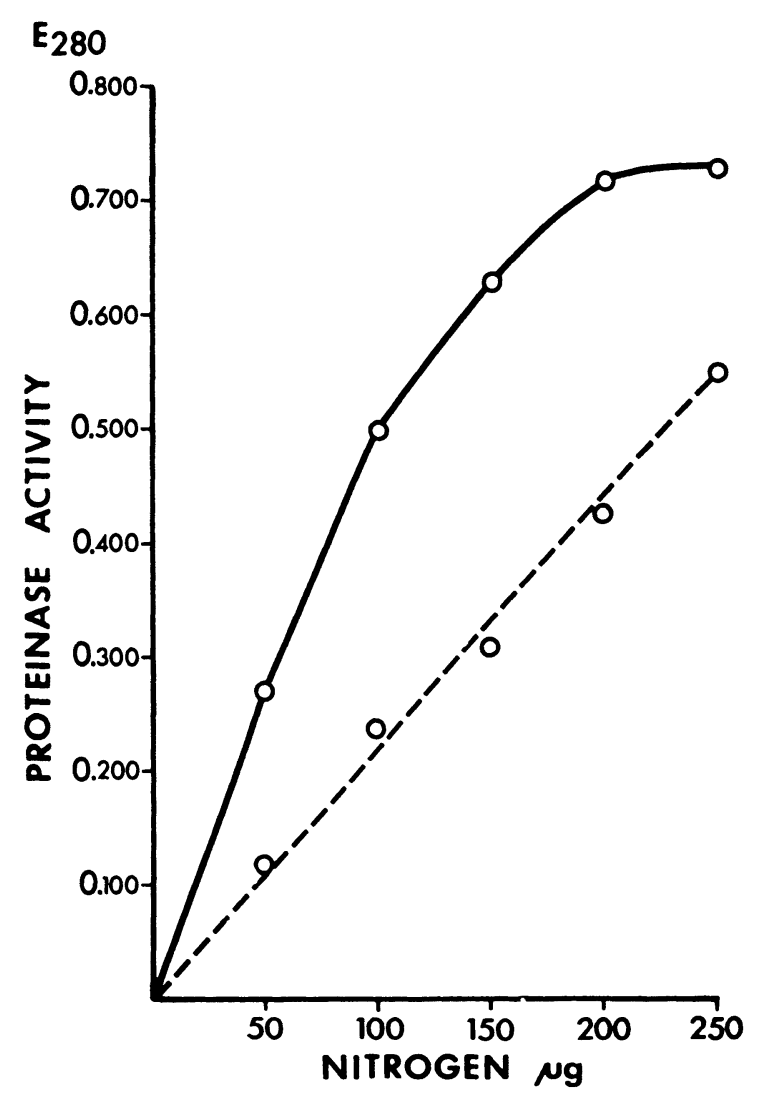

Figure 5. Proteinase activity in relation to nitrogen content. Aspergillus fumigatus strain 6869. Basic procedure of protein hydrolysis: a reaction mixture of $1 \mathrm{ml}$ of filtrate dilution, $1 \mathrm{ml}$ of $4 \%$ substrate solution and $2 \mathrm{ml}$ of buffer was incubated in a water bath at $45^{\circ} \mathrm{C}$ for $60 \mathrm{~min}$.

$0-0$ haemoglobinase activity at $\mathrm{pH} 4.6$.

$0----\infty$ caseinase activity at $\mathrm{pH} 6.2$.

following heat treatment at $50^{\circ} \mathrm{C}$, Fig. $7 \mathrm{~A}$ ) and the weakest activity in filtrates that had been heat treated at $\mathrm{pH} 10$ where no residual activity at all could be recorded after heat treatment at $40^{\circ} \mathrm{C}$ (Fig. 7D). On the other hand, the strongest residual caseinase activity at $\mathrm{pH} 10$ was recorded in filtrates that had been heat treated at $\mathrm{pH} 10\left(42 \%\right.$ following heat treatment at $50^{\circ} \mathrm{C}$, Fig. 7D) and the weakest activity in filtrates that had been heat treated at $\mathrm{pH} 3$ where only $2 \%$ residual activity could be de- 


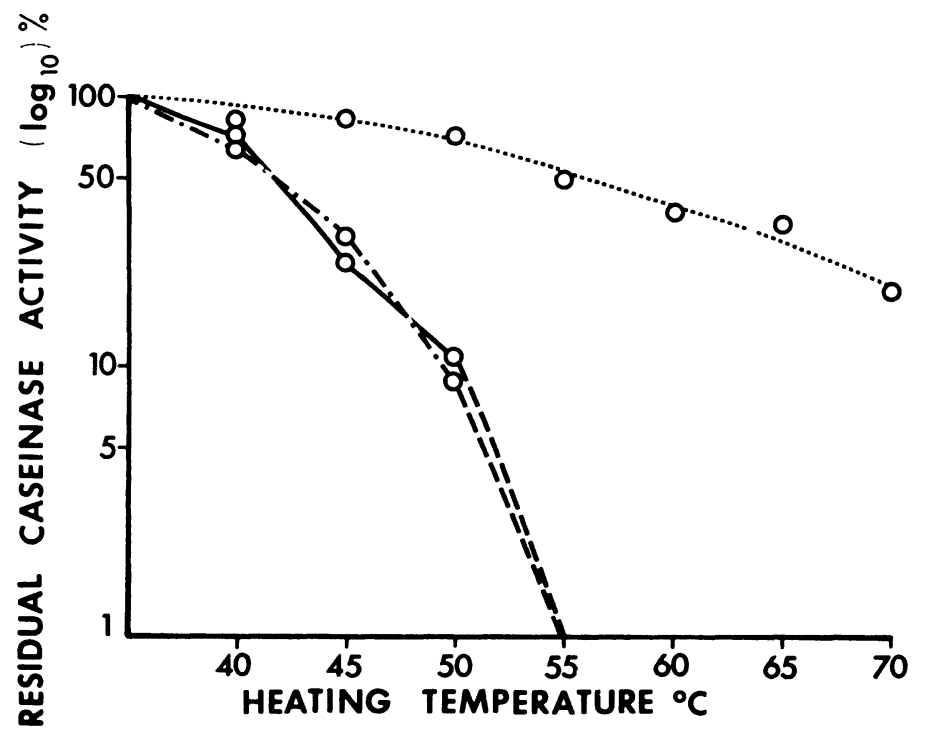

Fig u re 6. Thermal inactivation of caseinase activity of mycelial filtrate, $\mathrm{pH} 7,3$, Aspergillus fumigatus strain 6869 .

Dialyzed filtrate in volumes of $4 \mathrm{ml}$ in thin-walled, stoppered glass tubes was heated in a water bath at different temperatures for 2 hrs. After heating, the tubes were immediately cooled under running cold water and the residual caseinase activity at $\mathrm{pH} 2.9, \mathrm{pH} 6.2$, and $\mathrm{pH} 10$, respectively, was determined. Basic procedure of casein hydrolysis: a reaction mixture of $0.5 \mathrm{ml}$ of filtrate, $1 \mathrm{ml}$ of $4 \%$ casein solution and $2 \mathrm{ml}$ of buffer was incubated at $37^{\circ} \mathrm{C}$ for $90 \mathrm{~min}$.

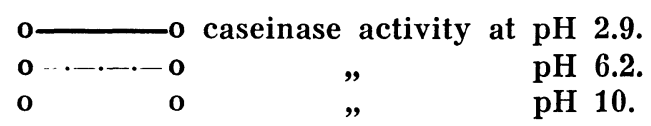

tected after heat treatment at $45^{\circ} \mathrm{C}$ and no activity at all after heat treatment at $50^{\circ} \mathrm{C}$ ( Fig. $7 \mathrm{~A}$ ). The caseinase activity at $\mathrm{pH}$ 6.2 showed greater stability in filtrates that had been heat treated at $\mathrm{pH} 3$ than did the caseinase activity at $\mathrm{pH} 10$ (Fig. 7A). Greater stability of caseinase activity at $\mathrm{pH} 6.2$ than that at $\mathrm{pH}$ 2.9 was found in filtrates that had been heat treated at $\mathrm{pH} 8$ or $\mathrm{pH}$ 10. (Figs. 7C, D). The strongest residual caseinase activity at any of the investigated $\mathrm{pH}$ values occurred in filtrates that had been heat treated at $\mathrm{pH} 5$ (Fig. 7B). The inactivating effect of $\mathrm{pH}$ per se on the caseinase activity at the $\mathrm{pH}$ values examined shows a basic similarity to previous investigations (Fig. 3). 


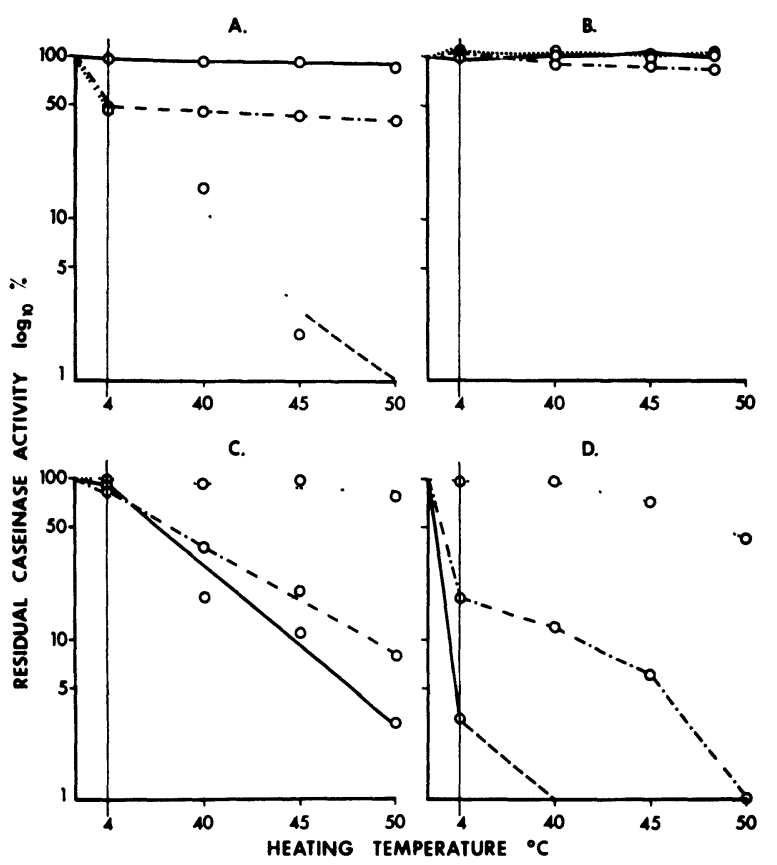

Fig u re 7. Thermal inactivation of caseinase activity of mycelial filtrate heated at (A) $\mathrm{pH} \mathrm{3,} \mathrm{(B)} \mathrm{pH} \mathrm{5,} \mathrm{(C)} \mathrm{pH} \mathrm{8}$, and (D) $\mathrm{pH} 10$ at different temperatures. Aspergillus fumigatus strain 6869 .

The filtrate in volumes of $4 \mathrm{ml}$ was adjusted to $\mathrm{pH} 3, \mathrm{pH} 5, \mathrm{pH} 8$, and $\mathrm{pH} 10$, respectively, transferred to thin-walled, stoppered glass tubes and heated in a water bath at different temperatures for $60 \mathrm{~min}$. After heating, the tubes were immediately cooled under running cold water. The filtrate was neutralized and the volumes corrected with distilled water. The residual caseinase activity of the filtrate at $\mathrm{pH} 2.9$, $\mathrm{pH} 6.2$, and $\mathrm{pH} 10$, respectively, was then determined. $0.1 \mathrm{~N}-1 \mathrm{~N}-\mathrm{HCl}$ or $0.1 \mathrm{~N}-1 \mathrm{~N}-\mathrm{NaOH}$ was used for $\mathrm{pH}$ adjustments. Basic procedure of casein hydrolysis: a reaction mixture of $0.5 \mathrm{ml}$ of filtrate, $1 \mathrm{ml}$ of $4 \%$ casein solution and $2 \mathrm{ml}$ of buffer was incubated at $37^{\circ} \mathrm{C}$ for $90 \mathrm{~min}$.

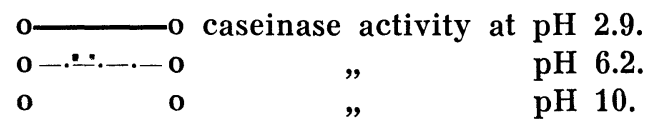

The divergent stability of the caseinase activity at $\mathrm{pH}$ values 2.9, 6.2 and 10 of dialyzed mycelial filtrates that had been heat treated at $45^{\circ} \mathrm{C}$ for $60 \mathrm{~min}$. can be seen in Fig. 8.

Effect of normal serum and antiserum on caseinase activity. It is seen (Table 1) that $0.2 \mathrm{ml}$ normal serum inhibited some $50 \%$ 


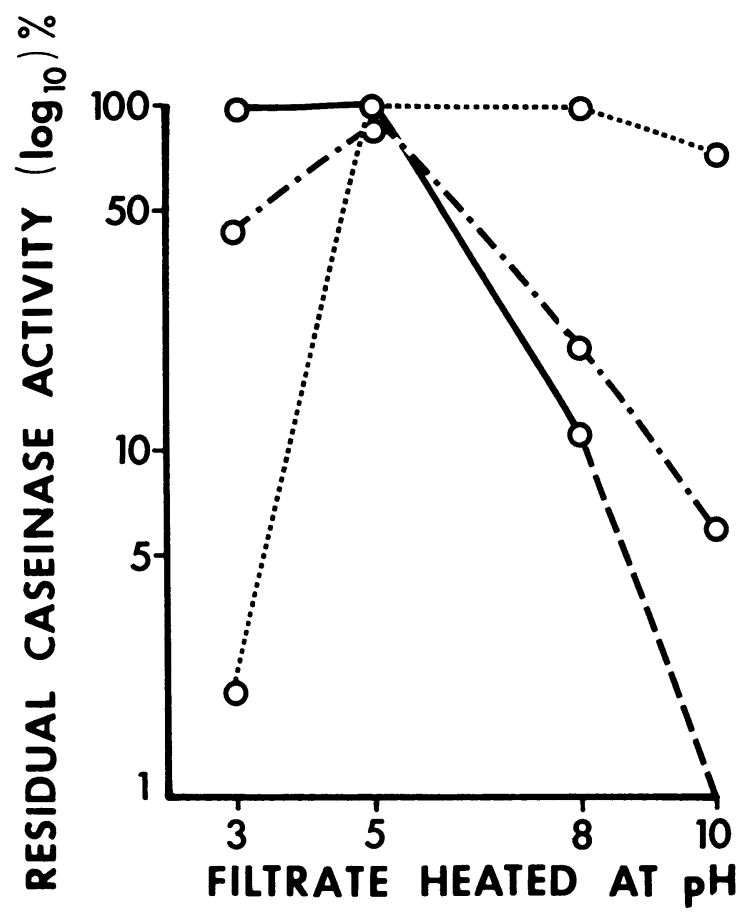

$\mathrm{F}$ i g u r e 8. Comparison of thermal inactivation of caseinase activity at $\mathrm{pH} 2.9, \mathrm{pH} 6.2$, and $\mathrm{pH} 10$, respectively, of mycelial filtrate heated at $\mathrm{pH}$ values $3,5,8$, and 10 , respectively, at $45^{\circ} \mathrm{C}$ for $60 \mathrm{~min}$. Aspergillus fumigatus strain 6869 . Basic procedure of casein hydrolysis: a reaction mixture of $0.5 \mathrm{ml}$ of filtrate, $1 \mathrm{ml}$ of $4 \%$ casein solution and $2 \mathrm{ml}$ of buffer was incubated at $37^{\circ} \mathrm{C}$ for $90 \mathrm{~min}$.

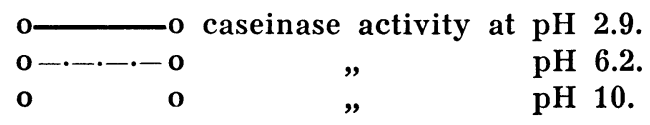

of the caseinase activity of $0.5 \mathrm{ml}$ filtrate at $\mathrm{pH} 2.9$ and $\mathrm{pH} 6.2$. Caseinase activity at pH 10 was almost completely inhibited. By increasing the amount of serum it was possible to achieve an additional, though slower, inhibition of the caseinase activity at $\mathrm{pH}$ values 2.9 and 6.2.

Antiserum produced no definite inhibition beyond that obtained by normal serum.

Effect of normal serum and antiserum on the casein precipitating activity. Electrophoretic separation of the normal sera and antisera used in these experiments showed that the $\gamma$-glo- 
T a b l e 1. Inhibitory effect of normal serum and antiserum from the rabbit on the casein hydrolyzing activity of mycelial filtrate. Aspergillus fumigatus strain 6869 .

\begin{tabular}{|c|c|c|c|c|c|c|}
\hline \multirow{3}{*}{$\begin{array}{c}\text { Amount } \\
\text { of serum } \\
\mu l\end{array}$} & \multicolumn{6}{|c|}{$\mathrm{E}_{280}$ (caseinase activity) } \\
\hline & \multicolumn{3}{|c|}{$\underset{\mathrm{pH}}{\text { Normal serum }}$} & \multicolumn{3}{|c|}{$\begin{array}{c}\text { Antiserum } \\
\text { pH }\end{array}$} \\
\hline & 2.9 & 6.2 & 10 & 2.9 & 6.2 & 10 \\
\hline 0 & $\left.0.695^{\star}\right)$ & 0.775 & 0.490 & 0.695 & 0.775 & 0.490 \\
\hline 200 & 0.335 & 0.415 & 0.055 & 0.335 & 0.285 & 0.040 \\
\hline 300 & 0.265 & 0.360 & 0.035 & 0.310 & 0.255 & 0.045 \\
\hline 400 & 0.215 & 0.320 & 0.035 & 0.320 & 0.260 & 0.050 \\
\hline 500 & 0.195 & 0.275 & 0.000 & 0.300 & 0.245 & - $\left.{ }^{\star *}\right)$ \\
\hline
\end{tabular}

*) All values are the means of 2 estimates.

**) Not investigated.

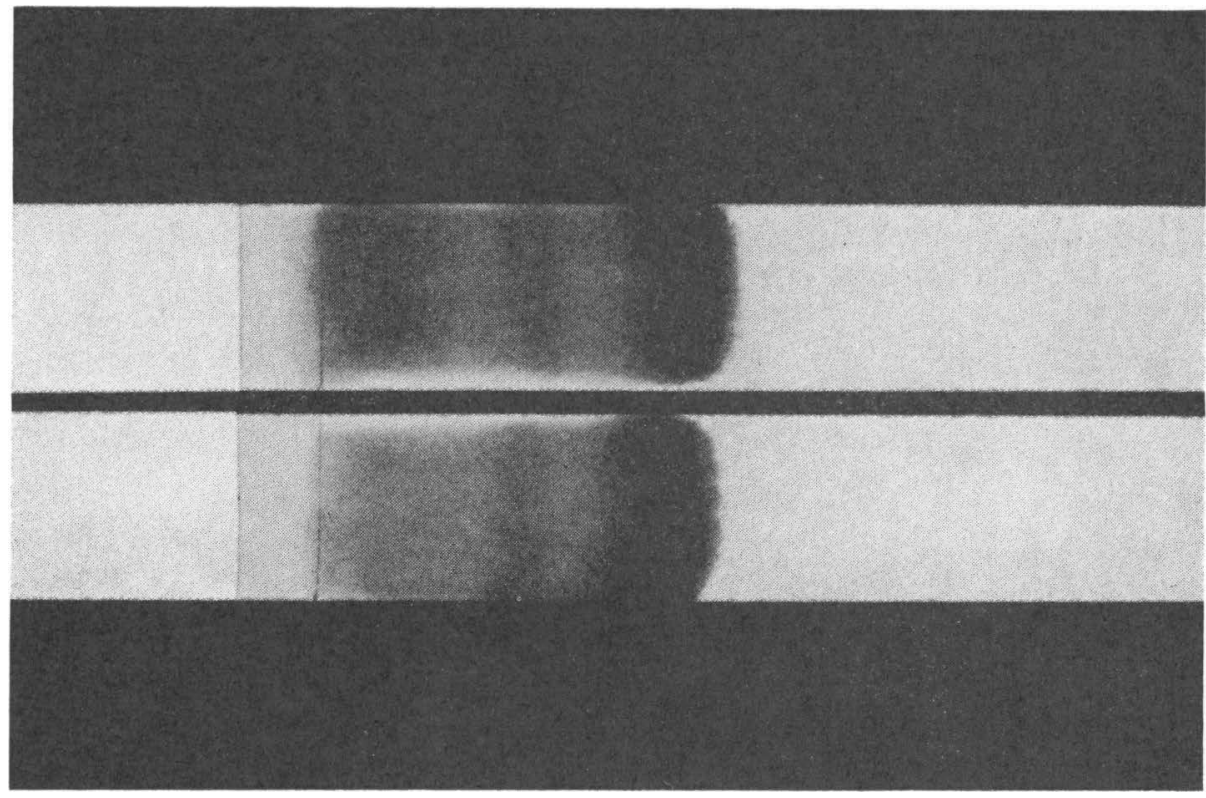

F ig u r e 9. Electrophoretic patterns of antiserum (upper electrophorogram) and normal serum (lower electrophorogram) of rabbit. Electrophoresis was run in $0.05 \mathrm{M}$ phosphate buffer for $17 \mathrm{hrs}$. with a current strength of 0.25 mamp. $/ \mathrm{cm}$.

The antiserum was prepared against mycelial filtrate from Aspergillus fumigatus strain 6869 . 
bulin content of the antiserum was more than twice that of the normal serum (viz. $2.58 \mathrm{~g} / 100 \mathrm{ml}$ in the antiserum and $1.05 \mathrm{~g} /$ $100 \mathrm{ml}$ in the normal serum). Under the prevailing conditions of electrophoresis and using a phosphate buffer of pH 6.4, only 2 distinct globulin fractions were obtained (Fig. 9).

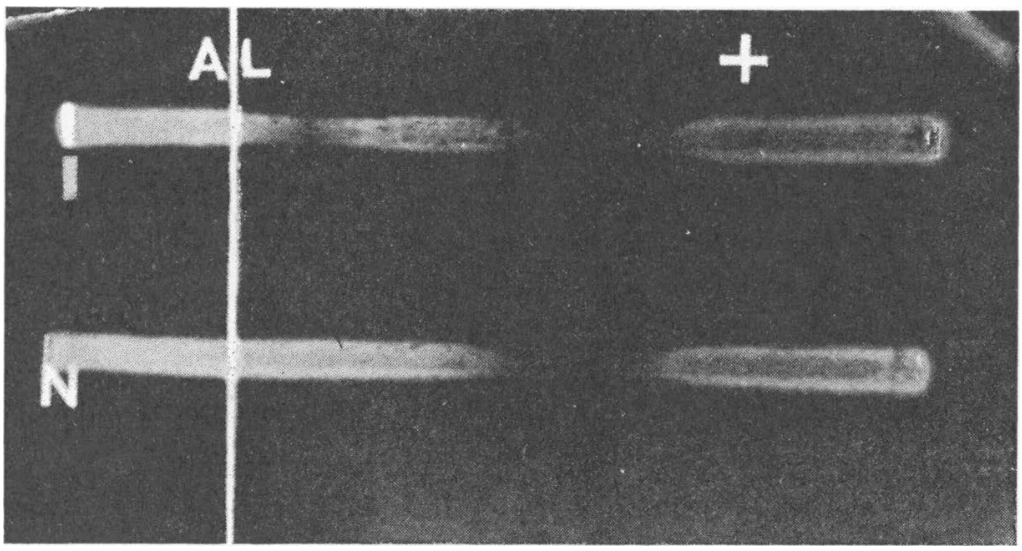

Figure 10 . Electrophoretic patterns of normal serum and antiserum from rabbit after being transferred to the surface of casein agar and influenced by casein precipitating enzyme of mycelial filtrate from Aspergillus fumigatus strain 6869, which was homologous to the antiserum.

$\mathrm{AL}=$ application line, $\mathrm{I}=$ antiserum, $\mathrm{N}=$ normal serum, $+=$ anode end.

The corresponding zones of inhibition of casein precipitating enzymes as seen in both the normal serum and the antiserum reflect natural inhibitors in the sera. The zone of inhibition near AL observed in the antiserum is caused by specific antienzyme.

As can be seen from Fig. 10 the casein precipitating enzymatic activity was inhibited by normal serum as well as antiserum within a range starting over the albumin fraction and extending towards the most mobile globulin fraction. With antiserum there was also a clear inhibition zone, corresponding to the position of the $\gamma$-globulin. Such inhibition of the casein precipitating ability of mycelial filtrate as caused by the $\gamma$-globulin fraction of the antiserum was also recorded when studying filtrates from each of the other 13 AF strains included in the investigations. 


\section{DISCUSSION}

Since the crude mycelial filtrate from AF showed very strong absorption at $280 \mathrm{~m} \mu$, dialyzed filtrate was used in all digestion tests. Maximum absorption of the dialyzed filtrate occurred at $275 \mathrm{~m} \mu$. This is the case with many simple proteins and amino acids (Hagihara 1954).

It is a quite common observation in the study of proteinase from various species of fungi that the proteolytic activity of a particular species shows more than one $\mathrm{pH}$ optimum at the same time (cf. Ito 1950a, b, Ghosh 1952, Crewther \& Lennox 1953a, b, Yamamoto 1957, Matsushima 1958, 1959 a, b, Singh \& Martin 1960, Jönsson \& Martin 1965, Narayanan \& Shanmugasundaram 1966, and others). Bergkvist (1963a,b), using Aspergillus oryzae, succeeded in isolating 3 different proteolytic enzymes, showing optimum activity at $\mathrm{pH} 4.3-4.5, \mathrm{pH} \quad 6.3-6.8$ and $\mathrm{pH} 7.6-9.5$, respectively. On casein and gelatin hydrolysis, nutrient broth used for growing AF displayed $3 \mathrm{pH}$ optima, viz. at $\mathrm{pH} 2.9, \mathrm{pH}$ 6.6 and pH 10 (Jönsson \& Martin 1964).

In the present investigation also, concentrating on the proteolytic activity of mycelial filtrate from AF, casein hydrolysis revealed $3 \mathrm{pH}$ optima (at $\mathrm{pH}$ values $2.9,6.2$ and 10; Fig. 2). There is thus a clear coincidence in this respect between the proteolytic activity of mycelial filtrate and the proteolytic activity of culture media used for cultivation of AF as reported by Jönsson \& Martin (1964) and by Martin \& Jönsson (1965). There was a distinct difference between the culture medium and the mycelial filtrate in that the caseinolytic activity of the former constantly had its maximum at $\mathrm{pH} 10$ whereas the caseinolytic activity of the latter was at its peak at $\mathrm{pH} 6.2$. It would seem close at hand to assume that the enzyme produced by the mycelium is transferred to the culture medium in which the mycelium is grown, by migration or autolysis. On this assumption the employment of culture media of various compositions may have resulted in the production of slightly different proteinase varieties in the 2 cases. This would account for the discrepancy noticed here. It may also be possible that the proteolytic activity at the $2 \mathrm{pH}$ values ( $\mathrm{pH} 6.2$ and 10 according to the present investigation, pH 6.6 and 10 according to Martin \& Jönsson 1965) may derive from different enzymes. That being the case the discrepancy may be explained by one enzyme being released from 
the mycelium and migrating into the culture medium to a greater extent than the other.

Like Singh \& Martin (1960) in their studies of proteinase from Penicillium cyano-fulvum, Bergkvist (1963a) in his studies of proteinase from Aspergillus oryzae, and others, the present author observed the lacking coincidence between the $\mathrm{pH}$ optima for casein hydrolysis caused by mycelial filtrate from $\mathrm{AF}$ and the $\mathrm{pH}$ optima for hydrolysis of haemoglobin (Fig. 2). In a previous paper (Rutquist 1969) the author demonstrated that the optimum $\mathrm{pH}$ value for gelatin hydrolysis caused by mycelial filtrate from AF was about 7, which does not coincide with the optimum $\mathrm{pH}$ value for the casein hydrolysis nor for the haemoglobin hydrolysis. This may very probably be attributed to different properties of the various substrates. It is interesting to note, however, that one of the $\mathrm{pH}$ optima for casein hydrolysis ( $\mathrm{pH} \mathrm{6.2)} \mathrm{is} \mathrm{identical} \mathrm{with} \mathrm{the} \mathrm{pH}$ optimum for the enzymatic precipitation of the casein complex (cf. Rutqvist 1969).

The caseinase activity at the $\mathrm{pH}$ values giving optimum casein hydrolysis ( $\mathrm{pH} 2.9, \mathrm{pH} 6.2$ and $\mathrm{pH} 10$ ) showed variations of stability after storing (at $4^{\circ} \mathrm{C}$ ) and subsequently neutralizing mycelial filtrate that had been adjusted to various $\mathrm{pH}$ values (Fig. 3). Following storage, the caseinase activity at $\mathrm{pH} 6.2$ and pH 10 displayed maximum stability at $\mathrm{pH} 4$, a value common to both, whereas the caseinase activity at $\mathrm{pH} 2.9$ showed its greatest stability at $\mathrm{pH}$ values $6-7$. It is interesting to note that maximum stability occurred at $\mathrm{pH}$ values other than the optimum $\mathrm{pH}$ values for protein hydrolysis.

A clear divergence of stability between the caseinase activity at $\mathrm{pH} 2.9, \mathrm{pH} 6.2$ and $\mathrm{pH} 10$ could also be demonstrated in filtrates that had been heated at $\mathrm{pH} 3, \mathrm{pH} 8$ and $\mathrm{pH} 10$, respectively (Figs. 7A,C,D and Fig. 8). Martin \& Jönsson, however, report that the caseinase activity at $\mathrm{pH} 6.6$ and $\mathrm{pH} 10$ of enzyme extracted from nutrient broth used for growing AF showed identical inactivation curves when being heated. These authors unfortunately do not state the $\mathrm{pH}$ value at which the heating took place. Assuming, like Martin \& Jönsson, that the same enzyme is responsible for the casein hydrolyzing activity at $\mathrm{pH} 6.2$ (pH 6.6 according to Martin \& Jönsson) and pH 10, the discrepancy between the results obtained by the present author and those of Martin $\&$ Jönsson in this respect may well be explained by the latter authors carrying out the heating at a $\mathrm{pH}$ value that by coin- 
cidence happened to cause identical inactivations of the caseinase activity at $\mathrm{pH} 6.6$ and that at $\mathrm{pH} 10$.

Martin \& Jönsson, under the influence of the uniformity of inactivation of the caseinase activity at $\mathrm{pH} 6.6$ and that at $\mathrm{pH} \mathrm{10,} \mathrm{together} \mathrm{with} \mathrm{the} \mathrm{results} \mathrm{of} \mathrm{their} \mathrm{chromatographic} \mathrm{and}$ electrophoretic investigations, put forward a hypothesis according to which these two $\mathrm{pH}$ optima for casein hydrolysis were caused by a single enzyme and would reflect the hydrolysis of different groups of peptide bonds which, to be attacked by the enzyme, would be dependent on different electronic charges within the substrate molecule and hence also on the $\mathrm{pH}$ value of the medium in which the reaction takes place.

The difference between $\mathrm{pH}$ inactivation and heat inactivation of the caseinase activity at $\mathrm{pH} 6.2$ and $\mathrm{pH} 10$ as demonstrated under various conditions in the present investigation, however, would rather speak in favour of the caseinase activity at these $\mathrm{pH}$ values reflecting different proteolytic principles.

Even if assuming that the proteolytic activity at $\mathrm{pH} 6.2$ and pH 10 may be caused by the same enzyme it would seem possible that the proteolytic activity at these $\mathrm{pH}$ values may derive from different active sites of the enzyme, with different stability against heat and/or hydrogen ion concentration.

The degradation of a substrate by an enzyme is influenced by 2 temperature factors acting simultaneously, viz. an increase in the initial degradation of the substrate per unit time associated with the rise in temperature, on one hand, and a gradual destruction of the enzyme, which is also linked up with the rise in temperature, with a resultant continuous drop in the concentration of the active enzyme, on the other.

Investigations of the effect of the incubation temperature on the casein hydrolyzing activity of mycelial filtrate from AF seem to indicate the existence of a broad temperature range of the caseinase activity at $\mathrm{pH} 6.2$, with an optimum at $45^{\circ} \mathrm{C}$ (Fig. $4 \mathrm{~B}$ ).

The optimum incubation temperature for casein hydrolysis at $\mathrm{pH} 2.9$ and $\mathrm{pH} 10$ was $40^{\circ} \mathrm{C}$ and $35^{\circ} \mathrm{C}$, respectively. At these $\mathrm{pH}$ values the caseinase activity had narrow temperature ranges, with very little or no caseinase activity even at incubation temperatures around 45 or $50^{\circ} \mathrm{C}$ (Figs. $4 \mathrm{~A}, \mathrm{C}$ ). It does not seem possible here to suggest thermal destruction of the enzyme as an explanation, knowing that (as may be seen from Figs. 7A and D) considerable caseinase activity at the relevant $\mathrm{pH}$ values was de- 
tected in mycelial filtrates that had been heated at $50^{\circ} \mathrm{C}$ at $\mathrm{pH} 3$ and $\mathrm{pH} 10$, respectively. The decreased or lacking ability of the proteolytic enzyme of breaking down casein at $\mathrm{pH} 2.9$ or $\mathrm{pH} 10$ during incubation at temperatures above $40^{\circ} \mathrm{C}$ and $35^{\circ} \mathrm{C}$, respectively, was not investigated. It is possible that under these environmental conditions the enzyme may be incapable of attaching itself to the substrate.

It has been known for a long time that normal serum from various animal species is capable of inhibiting bacterial proteinases (cf. Sandvik 1962, and others) and proteinases from microscopic fungi (cf. Stefanini \& Karaca 1963, Bergkvist 1963c, Sandvik 1967, and others). It may be assumed that the concentrations of the normal serum inhibitors may vary from one individual to another even whithin the same animal species. In the present investigation it was found that the casein hydrolysis caused by mycelial filtrate from $\mathrm{AF}$ at $\mathrm{pH} 2.9, \mathrm{pH} 6.2$ and $\mathrm{pH} 10$ was subjected to strong inhibition by normal rabbit serum. It was not possible, however, to demonstrate any definite inhibition of the casein hydrolysis, in addition to that caused by normal serum, by using rabbit antiserum in which the $\gamma$-globulin content exceeded that of normal serum by more than $240 \%$.

By applying the immuno-electrophoretic technique for serological differentiation of proteinases devised by Sandvik (1962, 1967) the present author succeeded in demonstrating, in the $\gamma$ globulin fraction of antiserum to mycelial filtrate from an AF strain, the presence of antibodies against casein precipitating enzymes in mycelial filtrates from the homologous strain as well as from 13 heterologous AF strains. This suggests immunological uniformity of the intracellular casein precipitating enzyme of the investigated AF strains and corresponds to the results published by Sandvik (1967), demonstrating close serological relationship between extracellular casein precipitating enzymes from 2 AF strains.

\section{REFERENCES}

Anson, M. L.: The estimation of pepsin, trypsin, papain and cathepsin with haemoglobin. J. gen. Physiol. 1938, 22, 79-89.

Bergkvist, R.: The proteolytic enzymes of Aspergillus oryzae I. Methods for the estimation and isolation of the proteolytic enzymes. Acta chem. scand. 1963a, 17, 1521-1540.

Bergkvist, R.: The proteolytic enzymes of Aspergillus oryzae II. Properties of the proteolytic enzymes. Acta chem. scand. 1963b, 17, 1541-1551. 
Bergkvist, R.: The proteolytic enzymes of Aspergillus oryzae IV. On the inhibition of the enzymes by serum. Acta chem. scand. $1963 \mathrm{c}, 17,2239-2249$.

Crewther, W. G. \& F. G. Lennox: Enzymes of Aspergillus oryzae III. The sequence of appearance and some properties of the enzyme liberated during growth. Aust. J. biol. Sci. 1953a, B 6, 410-427.

Crewther, W. G. \& F. G. Lennox: Enzymes of Aspergillus oryzae IV. Fractionation and preparation of crystals rich in protease. Aust. J. biol. Sci. 1953b, B 6, 428-446.

Dworschak, R. G., H. J. Koepsell \& A. A. Lagoda: Proteolytic enzymes of microorganisms. Evaluation of proteinase produced by molds of the Aspergillus flavus-oryzae group in submerged culture. Arch. Biochem. 1952, 41, 48-60.

Ghosh, J. J.: Studies on the dextrinase, amylase, protease and lipase activities of the riceinhabiting fungi. Indian J. Physiol. 1952, 6, $28-42$.

Hagihara, B.: Crystalline bacterial amylase and proteinase. A. R. Sci. Works (Fac. Sci. Osaka Univ.) 1954, 2, 35-80.

Ito, Y.: On the protease action of Penicillium notatum. I. J. Biochem. (Tokyo) 1950a, 37, 51-63.

Ito, Y.: On the protease action of Penicillium notatum. II. J. Biochem. (Tokyo) 1950b, 37, 237-247.

Jönsson, A. G. \& S. M. Martin: Protease production by Aspergillus fumigatus. Agric. Biol. Chem. (Tokyo) 1964, 28, 734-739.

Jönsson, A. G. \& S. M. Martin: Protease production by Alternaria tenuissima. Agric. Biol. Chem. (Tokyo) 1965, 29, 787-791.

Kunitz, M.: Crystalline soybean trypsin inhibitor. II. General properties. J. gen. Physiol. 1947, 30, 291-310.

Martin, S. M. \& A. G. Jönsson: An extracellular protease from Aspergillus fumigatus. Canad. J. Biochem. 1965, 43, 1745-1753.

Matsushima, K.: Studies on the proteolytic enzymes of molds. Part XIV. Classification of fungal protease systems by means of $\mathrm{pH}-$ activity curves. J. agric. Chem. Soc. (Tokyo) 1958, 32, 215-218.

Matsushima, K.: Studies on the proteolytic enzymes of molds. Part XV. Analysis of fungal protease systems by means of their $\mathrm{pH}-$ activity curves and inhibitors. J. agric. Chem. Soc. (Tokyo) $1959 \mathrm{a}, 33,116-120$.

Matsushima, K.: Studies on the proteolytic enzymes of molds. Part XVI. Protease system of Taka-diastase. J. agric. Chem. Soc. (Tokyo) 1959b, 33, 120-125.

Narayanan, A.S. \& E. R. B. Shanmugasundaram: Studies on proteinase of Fusarium vasinfectum ATK. Enzymologia 1966, 30, 279-289.

Rutqvist, L.: Studies on Aspergillus fumigatus; toxin production of different strains and serological comparison of the strains. Acta vet. scand. $1965,6,224-233$.

Rutqvist, L.: Studies on Aspergillus fumigatus; stability of haemolysin and toxin in crude filtrate. Acta vet. scand. 1968, 9, 350-363.

Rutqvist, L.: Studies on Aspergillus fumigatus; casein precipitating and proteolytic effects of mycelial filtrate. Acta vet. scand. 1969, $10,18-35$. 
Sandvik, O.: Studies on casein precipitating enzymes of aerobic and facultatively anaerobic bacteria. Thesis, Oslo 1962.

Sandvik, $O$. : Identification of moulds by serologic differentiation of their proteolytic enzymes. Acta path. microbiol. scand. 1967, $71,333-338$.

Singh, K. \& S. M. Martin: Purification and properties of a protease from Penicillium cyano-fulvum. Canad. J. Biochem. 1960, 38, $969-980$.

Stefanini, M. \& M. Karaca: Natural inhibitors of fungal protease. (Aspergillin O). Ann. N.Y. Acad. Sci. 1963, 103, 803-815.

Wallenfels, K.: Über die Messung der proteolytischen Aktivität von Enzympräparaten. (Determination of proteolytic activity of enzyme preparations). Biochem. Z. 1950, 321, 189-196.

Yamamoto, K.: Studies on Koji. Part III. Effects of cultural temperature on the production of mold protease. Bull. agric. Chem. Soc. (Tokyo) 1957, 21, 319-324.

\section{SUMMARY}

Mycelial filtrates from Aspergillus fumigatus (AF) hydrolyzed protein substrate buffered at various $\mathrm{pH}$ values. Using casein as sub-

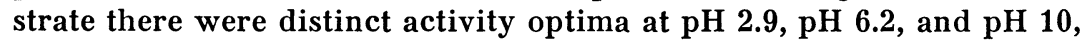
with maximum activity at $\mathrm{pH}$ 6.2. Using haemoglobin as substrate there were activity optima at $\mathrm{pH} 3.6, \mathrm{pH}$. 4.6, and $\mathrm{pH} \mathrm{10,} \mathrm{with} \mathrm{the}$ biggest activity peak at $\mathrm{pH}$ 4.6.

The $\mathrm{pH}$ stability at $4^{\circ} \mathrm{C}$ of the caseinase activity at $\mathrm{pH} 6.2$ and pH 10 was strongest at $\mathrm{pH} \mathrm{4,} \mathrm{common} \mathrm{to} \mathrm{both,} \mathrm{whereas} \mathrm{the} \mathrm{caseinase}$ activity at $\mathrm{pH} 2.9$ showed maximum $\mathrm{pH}$ stability at $\mathrm{pH} 6-7$.

The casein hydrolyzing activity at $\mathrm{pH} 2.9, \mathrm{pH} 6.2$, and $\mathrm{pH} 10$ showed different optimum incubation temperatures and irregular heat inactivation.

Normal rabbit serum inhibited the caseinase activity at $\mathrm{pH} 2.9$ and $\mathrm{pH} 6.2$ to some extent. The caseinase activity at $\mathbf{p H} 10$ was almost completely inhibited. Antiserum against mycelial filtrate showed no definite inhibition beyond that exerted by normal serum.

Following electrophoresis of antiserum, the presence of specific neutralizing antibodies against the casein precipitating enzyme of mycelial filtrate from AF could be established. Investigations of 14 AF strains showed immunological uniformity with respect to the casein precipitating enzyme.

\section{ZUSAMMENFASSUNG \\ Studien über Aspergillus fumigatus; Eigenschaften der intracellulären Proteinase.}

Die Myzelienfiltrate von Aspergillus fumigatus (AF) hydrolysierten gepufferte Proteinlösungen bei verschiedenen $\mathrm{pH}-$ Werten. Mit Kasein als Nährboden traten deutliche Aktivitätsoptima bei pH 2,9, pH 6,2 und pH 10 auf, wobei die Aktivität bei $\mathrm{pH} \mathrm{6,2} \mathrm{am} \mathrm{stärksten} \mathrm{war.}$ Bei Anwendung von Hämoglobin als Nährboden traten die Aktivitäts- 
optima bei $\mathrm{pH} \mathrm{3,6,} \mathrm{pH} \mathrm{4,6} \mathrm{bzw.} \mathrm{pH} 10$ mit dem höchsten Aktivitätswert bei $\mathrm{pH} 4,6$ auf.

Die pH-Stabilität für die Kaseinase-Aktivität bei $\mathrm{pH} 6,2$ bzw. $\mathrm{pH}$ 10 war am stärksten bei ein und demselben $\mathrm{pH}$-Wert nämlich $\mathrm{pH} \mathrm{4}$, während die Kaseinase-Aktivität bei $\mathrm{pH} 2,9$ die grösste pH-Stabilität bei $\mathrm{pH} 6-7$ aufwies.

Die Kasein-hydrolysierende Aktivität bei pH 2,9, pH 6,2 bzw. pH 10 hatte verschiedene optimale Inkubationstemperaturen und verschiedenartige Wärme-Inaktivierung.

Kaninchennormalserum hemmte teilweise die Kaseinase-Aktivität bei pH 2,9 bzw. 6,2. Die Kaseinase-Aktivität bei pH 10 wurde praktisch vollständig inhibiert. Ein gegen Myzelienfiltrat hergestelltes Antiserum gab keine stärkere Hemmung als Normalserum.

Nach Elektrophorese des Antiserums konnten in der Gammaglobulinfraktion spezifische neutralisierende Antikörper gegen das Kasein-präzipitierende Enzym im AF-Myzelienfiltrat nachgewiesen werden. Die Untersuchung von $14 \mathrm{AF}-$ Stämmen zeigte immunologische Einheitlichkeit in bezug auf das Kasein-präzipitierende Enzym.

\section{SAMMANFATTNING \\ Studier av Aspergillus fumigatus; egenskaper hos intracellulärt proteinas.}

Myceliefiltrat från Aspergillus fumigatus (AF) hydrolyserade proteinsubstrat buffrat vid olika $\mathrm{pH}$-värden. Med kasein som substrat uppträdde distinkta aktivitetsoptima vid $\mathrm{pH} 2,9, \mathrm{pH} \mathrm{6,2}$ och $\mathrm{pH} 10$. varvid aktiviteten vid $\mathrm{pH}$ 6,2 var störst. När hämoglobin användes som substrat uppträdde aktivitetsoptima vid $\mathrm{pH} 3,6, \mathrm{pH} \mathrm{4,6}$ respektive $\mathrm{pH}$ 10 med den största aktivitetstoppen vid $\mathrm{pH} \mathrm{4,6}$.

pH-stabiliteten för kaseinasaktivitet vid $\mathrm{pH} 6,2$ respektive $\mathrm{pH} 10$ var störst vid ett och samma $\mathrm{pH}$-värde nämligen $\mathrm{pH} \mathrm{4,} \mathrm{medan} \mathrm{kaseinas-}$ aktiviteten vid $\mathrm{pH} 2,9$ visade största $\mathrm{pH}$-stabiliteten vid $\mathrm{pH} 6-7$.

Kaseinhydrolyserande aktivitet vid respektive $\mathrm{pH} 2,9$, $\mathrm{pH} 6,2$ och pH 10 hade olika optimala inkuberingstemperaturer och olikformig värmeinaktivering.

Normalserum från kanin inhiberade partiellt kaseinasaktiviteten vid respektive $\mathrm{pH} 2,9$ och $\mathrm{pH}$ 6,2. Kaseinasaktiviteten vid pH 10 inhiberades praktiskt taget fullständigt. Antiserum till myceliefiltrat gav ingen säker inhibition utöver normalserumets.

Efter elektrofores av antiserum kunde i gamma-globulinfraktionen påvisas specifika neutraliserande antikroppar mot det kaseinprecipiterande enzymet i AF-myceliefiltrat. Undersökning av 14 AF-stammar visade immunologisk uniformitet för det kaseinprecipiterande enzymet.

(Received January 25, 1969). 